\title{
THE IMPACT OF SITE ATTRACTION AND SERVICE QUALITY ON LOYALTY THROUGH SATISFACTION: A CASE STUDY IN GUNUNG SEWU UNESCO GLOBAL GEOPARK, INDONESIA
}

\author{
Budiono SULISTYADI* \\ Technologi University of Yogyakarta, Kampus I UTY, Ring Road Utara, Sleman, \\ Yogyakarta 55285, Indonesia, e-mail: budionosulistyadi@gmail.com \\ Nur WENING \\ Technologi University of Yogyakarta, Kampus I UTY, Ring Road Utara, Sleman, \\ Yogyakarta 55285, Indonesia, e-mail: wening104@yahoo.co.id \\ Tutut HERAWAN \\ AMCS Research Center, Griya Perwita Wisata B-14, Jl. Kaliurang KM 12.5, \\ Sleman, Yogyakarta 55581, Indonesia, e-mail: tutut@uty.ac.id
}

\begin{abstract}
Citation: Sulistyadi, B., Wening, N., \& Herawan, T. (2019). THE IMPACT OF SITE ATTRACTION AND SERVICE QUALITY ON LOYALTY THROUGH SATISFACTION: A CASE STUDY IN GUNUNG SEWU UNESCO GLOBAL GEOPARK, INDONESIA. GeoJournal of Tourism and Geosites, 25(2), 509-523. https://doi.org/10.30892/gtg.25219-377
\end{abstract}

\begin{abstract}
This study aims to provide information for management to increase the number of tourist visits of Nglanggeran in Gunung Sewu UNESCO Global Geopark, Indonesia. Questionnaire using a Likert scale is the research instrument. The respondents are visitors of Nglanggeran tourist destination. The analysis technique is path analysis implemented on SmartPLS 3.0. This study examined the impact of site attraction and service quality on loyalty through satisfaction. The results found that site attraction has direct effect on satisfaction and loyalty but not significant, meanwhile service quality has direct and significant effect on satisfaction and loyalty, and satisfaction has direct effect on loyalty but not significant. Hence, increasing site attraction will provide opportunities for management to affects satisfaction and loyalty which can ultimately increase the number of tourist visits.
\end{abstract}

Keywords: Site attraction, Service quality, Loyalty, Satisfaction, Geopark, Path analysis, Nglanggeran

\section{INTRODUCTION}

The tourism sector plays an important role in supporting the economy of a region. This sector has a multiplier effect on industries that run and support the tourism sector, including hotels, restaurants, crafts, and transportation. Tourism is the world's largest

\footnotetext{
* Corresponding author
} 
and fastest-growing industry and is a major economic, environmental and sociocultural dynamic force (Haarhoff \& De Klerk, 2019). Global Geoparks Network (GGN) is a network under the auspices of UNESCO which was formed in 2001 with the purpose of finding and promoting the conservation of geological heritage and encouraging sustainable research and development in the community (Nikolova \& Sinnyovsky, 2019). According to the European Geoparks Network (EGN) charter and Global Geopark Network regulations in 2000, all geoparks have to be established in rural areas (Zouros \& Martini, 2003). Geoparks, as an innovation for the protection of natural and geological heritages, play an important role in the development of geotourism. Hence, geoparks and geotourism are opportunities for rural development, and they reduce the rate of unemployment and migration in rural areas (Farsani et al., 2010).

In 2004, UNESCO determined that geopark is an area that has prominent geological elements including archaeological, ecological and cultural values where local people are invited to play a role in protecting and improving the function of natural heritage (Nikolova \& Sinnyovsky, 2019). Nglanggeran tourist destinationis one sites of Gunung Sewu UNESCO Global Geopark in Gunungkidul district. It is an ancient volcano which was an active volcano around 60 million years ago, originating from the seabed volcano which has been lifted and has very distinctive rocks because it is dominated by agglomerates and volcanic breccias (MualMaul, 2009). Nglanggeran is located $25 \mathrm{~km}$ east of Yogyakarta city Indonesia, in Gunung Sewu UNESCO Global Geopark area (Figure 1).

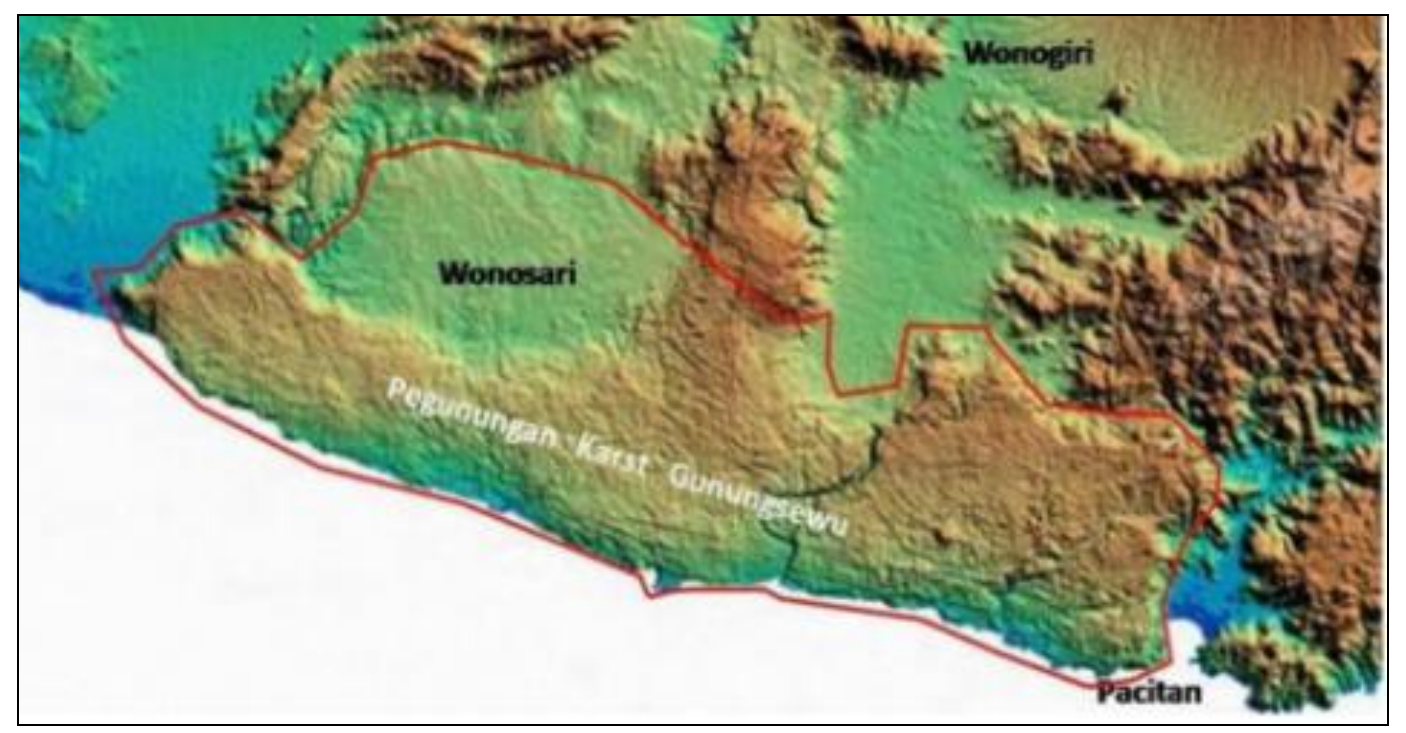

Figure 1. Gunung Sewu UNESCO Global Geopark area (Source: Pawonsari, 2013)

The height of Nglanggeran as depicted in Figure 2 is 700 meters above of sea level, the mountainous area reaches 48 hectares with interesting natural scenery. At an altitude of $500 \mathrm{~m}$ above sea level there is an Embung, that is a $5000 \mathrm{~m}^{3}$ rainwater storage pond that serves to irrigate the surrounding plants (Tourist Services of Gunungkidul District, 2018). Nglanggeran tourist area is managed by youth communities in the village of Nglanggeran, to help improve the economy of the surrounding area.

Nglanggeran tourist destination is one of the leading sites among 13 sites Gunung Sewu UNESCO Global Geopark in Gunungkidul district (Table 1). 
The Impact of Site Attraction and Service Quality on Loyalty Through Satisfaction:

A Case Study in Gunung Sewu Unesco Global Geopark, Indonesia

In 2010, Gunung Sewu Geopark was designated as the National Geopark (Martono, 2016). In 2015 it was crowned as a Global Geopark by UNESCO in the $4^{\text {th }}$ AsiaPacific Geoparks Network San'in Kaigan Symposium, Tottori city Japan. Since it was established as the National Geopark, the number of tourist visits in Gunung Sewu Geopark has increased, and since it was named the Global Geopark by UNESCO the number of tourist visits has increased and has begun to be visited by foreigners.

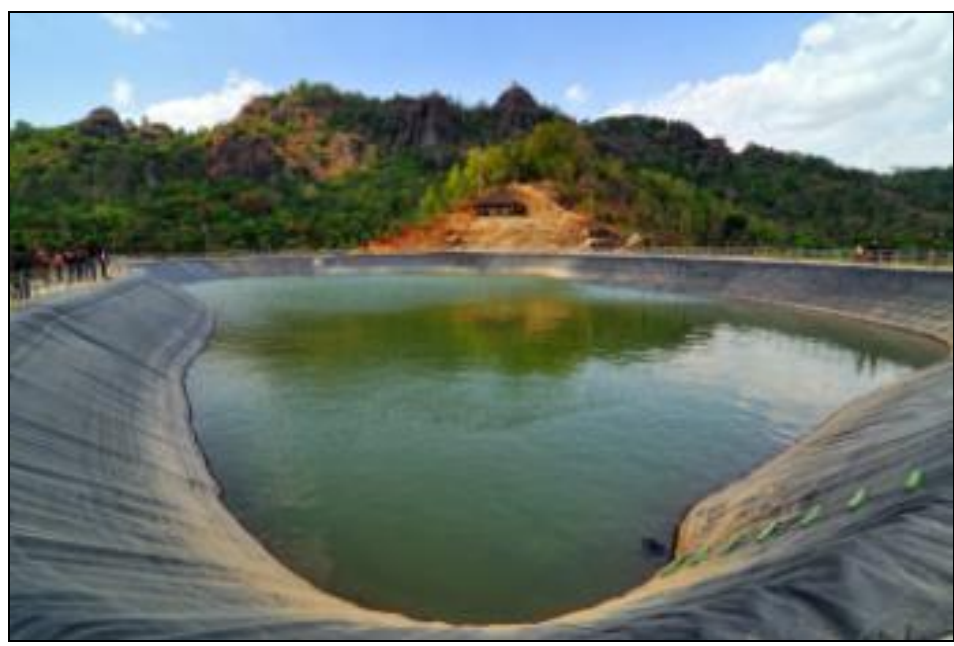

Figure 2. Nglanggeran Tourist Destination (Source: Samsudin, 2014)

Table 1. 13 sites of Gunung Sewu UNESCO Global Geopark in Gunungkidul District (Data source: Pawonsari, 2013)

\begin{tabular}{|c|l|l|}
\hline No & \multicolumn{1}{|c|}{ Site } & \multicolumn{1}{c|}{ Information } \\
\hline 1 & Nglanggeran & Volcanic breccias \\
\hline 2 & Sambipitu & Sedimentary structure \\
\hline 3 & GuaPindul & Endokarst phenomenon \\
\hline 4 & Kali Suci & Endokarst\&exokarst phenomenon \\
\hline 5 & Jomblang & Endokarst phenomenon \\
\hline 6 & Siung-Wediombo & Rocks, geological and geomorphological structures \\
\hline 7 & Sadeng & Karst geomorphological \\
\hline 8 & Bleberan & Geological structure \\
\hline 9 & Jlamprong & Endokarst phenomenon \\
\hline 10 & Cokro & Endokarst phenomenon \\
\hline 11 & Ngingrong & Endokarst phenomenon \\
\hline 12 & Wanagama & Flora and fauna \\
\hline 13 & Turunan & Flora and fauna \\
\hline
\end{tabular}

In 2015, the number of tourist visits in Nglanggeran has sharply increased from 2014, which amounted to $72.52 \%$. However, it decreased, in 2016 is $7.64 \%$, 2017 is $11.15 \%$, and in 2018 is $6.15 \%$. Although in 2017 the number of foreign tourist arrivals increased by $133 \%$ from 2016, it decreased in 2018 by 3.29\% (Tourist Services of Gunungkidul District, 2019). The number of tourists visited in Nglanggeran in 2014 - 2018 as depicted in Figure 3.

From Figure 3, in year 2014, there are no foreign tourists, meanwhile for domestic tourists are 107,000 (Tourist Services of Gunungkidul District, 2015); in 2015 there are no foreign tourists, meanwhile for domestic tourists are 184,600 (Tourist 
Services of Gunungkidul District, 2016); in 2016 there are 771 foreign tourists and 169,729 domestic tourists (Tourist Services of Gunungkidul District, 2017); in 2017 there are 1,794 foreign tourists and 149,703 domestic tourists (Tourist Services of Gunungkidul District, 2018); and in 2018 there are 1,735 foreign tourists and 140,444 domestic tourists (Tourist Services of Gunungkidul District, 2019).

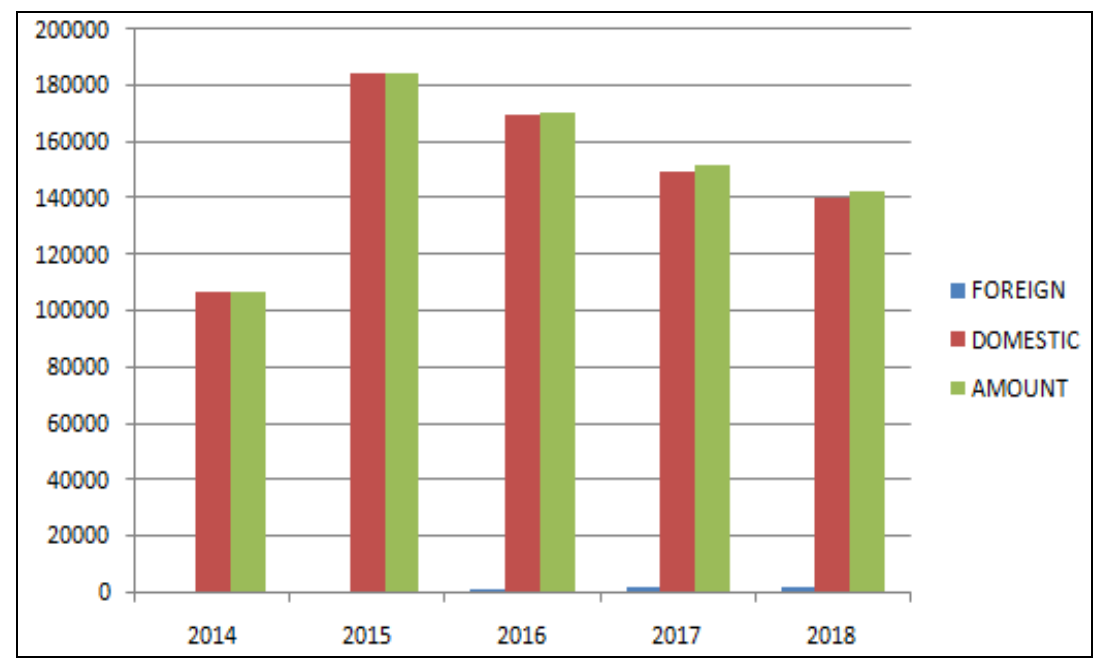

Figure 3. Tourist Visits in Nglanggeran

(Sources: Tourist Services of Gunungkidul District, 2015, 2016, 2017, 2018, 2019)

Motivated from above explanation, this study aims to provide information for management to increase the number of tourist visits of Nglanggeran in Gunung Sewu UNESCO Global Geopark Gunungkidul district, Yogyakarta, Indonesia. We discuss the impact of site attraction and service quality on loyalty through satisfaction to find out the relationships and the appropriate strategies to increase the number of tourist visits.

The primary data is obtained from respondents who are visitors of Nglanggeran tourist destination, through a research conducted in February 2019. Questionnaire is developed in the form of a checklist using a Likert scale as the research instrument, by investigating the following matters:

a. What is the relationship between site attraction variable and service quality variable on satisfaction and loyalty variables?

b. How does the site attraction variable, service quality variable, and satisfaction variable influence on loyalty variable?

Further analysis is needed to determine the impact of site attraction and service quality on loyalty through satisfaction, as an effort to increase the number of tourist visits in Nglanggeran. The analysis used is quantitative approach using path analysis techniques. A relationship model of variables is formed by using intervening variable or moderating variable cannot be solved by multiple regressions. Path analysis can be used to estimate the direct effect, indirect influence, and total influence between variables in the model (Wright, 1934). Thus, the analysis technique used to solve the variable relationship model that uses intervening variable is with path analysis. This study estimates and explains causally related the impact of site attraction and service quality on loyalty through satisfaction, thus, the appropriate analysis technique used is path analysis. The results will be valuable inputs for the management of Nglanggeran tourist destination. 
The Impact of Site Attraction and Service Quality on Loyalty Through Satisfaction:

A Case Study in Gunung Sewu Unesco Global Geopark, Indonesia

\section{RELATED WORKS AND PROPOSED HYPOTHESES}

This section presents review on existing works related to this research and our proposed hypotheses.

\section{Site Attraction}

Site attraction is an individual's perception of the characteristics of a destination that can be influenced by promotional information, mass media and many other factors (Tasci \& Kozak, 2006). Site attraction is an important factor that influences the demand for increased tourist visits because it greatly determines tourists in choosing their destinations. Tourist facilities are supporting facilities that can create a pleasant feeling accompanied by the ease and fulfillment of the needs of tourists in enjoying tourism products offered. Tourist facilities are divided into two parts, namely primary facilities with functions as the main tourist attraction, and supporting facilities (Burton, 1995). Dimensions and indicators include attractions, accessibility, facilities, management of site attractions (Saboohi et al., 2014).

\section{Service Quality}

Service is all activities or basically intangible benefits that can be given to others but do not cause any ownership (Chaffey, 2009). Service is any action or performance that can be offered to other parties, which is basically intangible and does not result in ownership (Scheidt \& Chung, 2019). Service is all activities, actions, performance, or basically intangible benefits that can be given to other parties without causing any ownership. The quality is a dynamic condition that relates to products, services, people, processes, and environments that meet or exceed expectations. Quality is the overall characteristics and characteristics of a product or service that affects its ability to satisfy expressed or implied needs. Quality is a dynamic condition or overall characteristics related to products, services, people, processes, and environment, which affect their ability to meet or exceed expectations for implied needs. Service quality is an attitude from the results of the comparison of the quality of customer service with the company's performance perceived by consumers (Usmara, 2008). Roderick \& Gregory (2008) stated that service quality is the level of performance measure assumed to be related to the price development. Service quality is the feeling that the customers have after purchasing service and implies whether or not they are satisfied with the service (Belber \& Erdogan, 2019). Service quality is a measure of the expected level of superiority in the performance of a product or service associated with price developments.

Service quality is one of the most important means of generating customer satisfaction and customer loyalty (Kesari \& Atulkar, 2016). Service quality dimension consist of tangible, empathetic, reliability, responsiveness, and assurance (Meesala \& Paul, 2016). Indicators of service quality include cleanliness of facilities, neatness of appearance of employees, personal attention by employees, pay attention to customer needs, provide service as promised, provide fast service, ability of employees in the field of services provided, friendliness of employees in providing services.

\section{Loyalty}

According to Mowen and Minor (1998), loyalty is a condition where the customer has a positive attitude towards a brand, has a commitment to the brand, and intends to continue its purchase in the future. Loyalty shows the tendency of customers to use a brand with a high level of consistency (Fang, 2019). Guchait et al., (2019) mention the reasons an institution needs to gain customer loyalty. Firstly, existing customers are more prospective, the cost of getting new customers is greater than retaining existing customers, customers who already believe will believe in other things, operating costs will be efficient if you have lots of loyal customers, you can reduce psychological and 
social costs because old customers have had positive experiences together, and loyal customers will be loyal and try to attract other people to become customers. Loyalty dimension consist of making regular repeat purchases, purchases across product and service lines, refers others, and demonstrates immunity to the pull of the competition (Griffin \& Moorhead, 2010). Loyalty indicators include saying positive things, recommending other parties, encouraging friends and relatives, considering the first choice to buy services, and doing more business (Gremler \& Brown, 1996).

\section{Satisfaction}

Satisfaction is the feeling of likes or dislikes of a product after comparing the performance of the product with expectations (Iglesias et al., 2019). Satisfaction is a positive emotional response to the evaluation of experience using a product or service (Wilkie, 1994). Martinaityte, et al. (2019) stated that satisfaction is an evaluation of product purchases that have the same or more value than expected. Satisfaction has an understanding of the difference between expectations and perceived values. Satisfaction is the main factor that can attract loyalty. Customer's satisfaction leads to customer's loyalty, recommendation and repeat purchase (Wilson et al., 2008). Satisfaction can be seen from the pride of the product, the fulfillment of customer desires, and the pleasure of the product provider. Satisfaction dimension consist of product quality, relationship marketing, loyalty promotion, best customers, complaint services, unconditional guarantees, and pay for performance. Satisfaction indicators include pleasure, suitability of expectations, satisfying, experience, and trust (Taylor \& Baker, 1994).

\section{Hypotheses}

This study examines the impact of site attraction and service quality on loyalty through satisfaction. The following hypotheses were elaborated:

H1: Site attraction has a significant influence on loyalty.

H2: Service quality has a significant influence on loyalty.

H3: Site attraction has a significant influence on satisfaction.

H4: Service quality has a significant influence on satisfaction.

$\mathrm{H}_{5}$ : Satisfaction has a significant influence on loyalty.

According to the proposed hypotheses, the following Figure 4 depicts the variable relationship which shows the relationship between the independent variable on the mediator variable and the dependent variable, as well as the relationship between the mediator variable and the dependent variable.

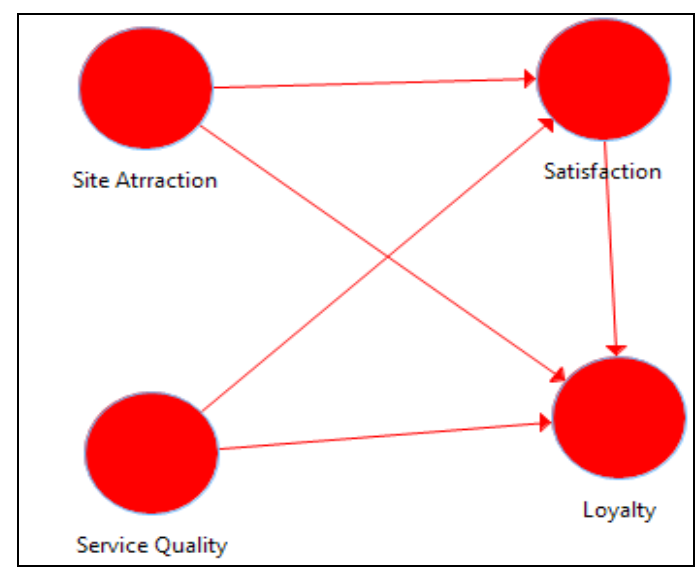

Figure 4. Variable Relationship 
The Impact of Site Attraction and Service Quality on Loyalty Through Satisfaction:

A Case Study in Gunung Sewu Unesco Global Geopark, Indonesia

Where independent variables are Site Attraction and Service Quality; mediator variable is Satisfaction; and dependent variable is Loyalty. The mathematical equation model proposed for the influence received by the satisfaction variable and loyalty variable is given as (Ghozali \& Latan, 2015):

Satisfaction $=\beta$ Site_Attraction $+\beta$ Service_Quality $+\varepsilon$

Loyalty $=\beta$ Site_Attraction $+\beta$ Service_Quality $+\beta$ Satisfaction $+\varepsilon$

$\beta=$ path coefficient

$\varepsilon=\sqrt{1-R^{2}}$

\section{DATA AND PROPOSED METHOD}

This section presents the data obtained and the proposed method.

\section{Data}

Tourists visited Nglanggeran tourist destination from years 2014 to 2018 is the population in this study. Primary data is directly obtained from the respondents of tourists visiting Nglanggeran tourist destination. Questionnaire in the form of a checklist using a Likert scale is the research instrument. Data collection is carried out in February 2019. From 50 respondents involded; $41 \%$ of them are males, and the other $59 \%$ are females. The classification of age is as follows: up to 30 years old are $74 \%$, and above 31 years old are $26 \%$. The education level of respondent is up to Diploma's degree are $70 \%$, Bachelor's degree are $22 \%$, and master's degree are $8 \%$.

The visitors are $70 \%$ personal, and 30\% group. The frequency of respondents' visits: one-time visit are $67 \%$, two times visit are $22 \%$, and more than two times visit are 11\%. The frequency of tourists visit is depicted in Figure 5.

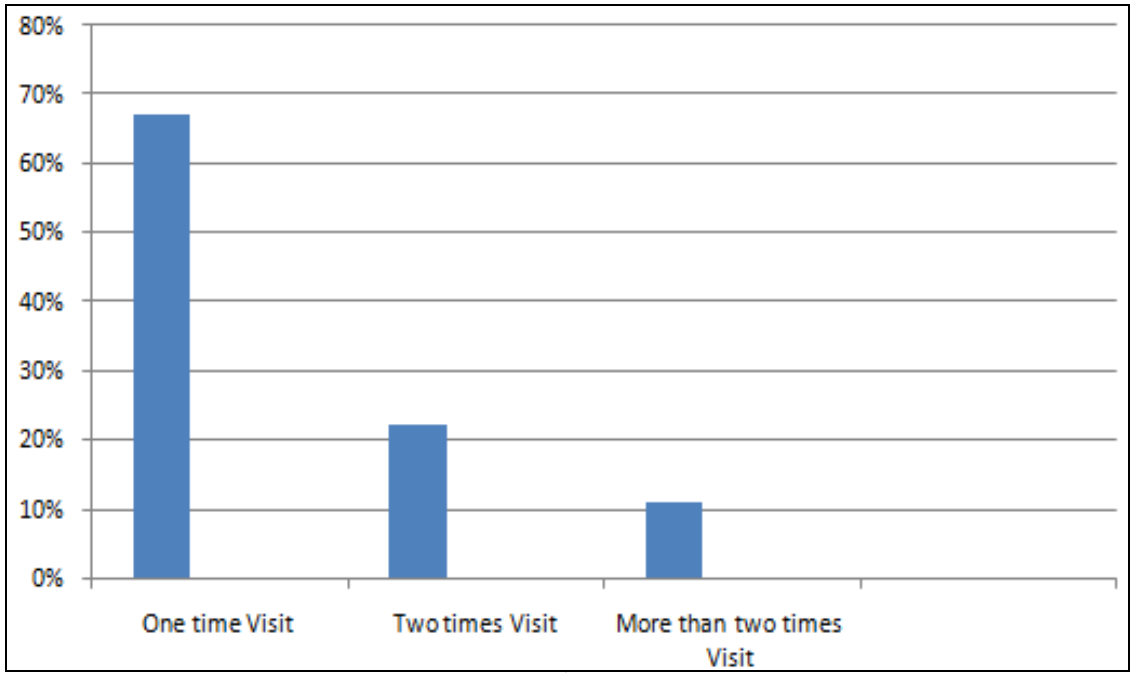

Figure 5. The Frequency of Respondents' Visit

\section{Research Methods}

Data analysis in this study includes data processing, data organizing, and finding results. A model that is formed as in Figure 4 using intervening or moderating variables cannot be solved by multiple regression, thus the appropriate analysis technique used to solve is path analysis. Path analysis can be used to estimate the direct effect, indirect influence, and total influence between variables in the model (Wright, 1934). The 
structural equation described by the path diagram is considered as a representation of the theory; hence the relationship between latent variables is a manifestation of the theory. The analysis technique in this research is the path analysis implemented on SmartPLS 3.0.

\section{RESULTS AND DISCUSSION}

There are four variables in this study with respective ten questions. They are site attraction A1-A10, service quality Q1-Q10, satisfaction S1-S10, and loyalty L1-L10.

\section{Measurement (Outer) Model Test}

The measurement model test is needed for path analysis with an unobserved variable. The outer model defines how each indicator relates to its latent variables. The outer model test is done to ensure that the measurements used are feasible to be used as measurements, which are valid and reliable. The outer model test is seen from several indicators, namely, convergent validity, discriminant validity, and undimensionality.

a. Convergent validity

Convergent validity with a reflection indicator can be seen from the correlation between indicator score and its variable score, namely, the value of the loading factor in the latent variable with the indicators. Indicators are considered reliable if they have a value of loading factor $>0.70$. The output estimation I is depicted in Figure 6 and the outer loadings I is described in Table 2 of path analysis using SmartPLS 3.0.

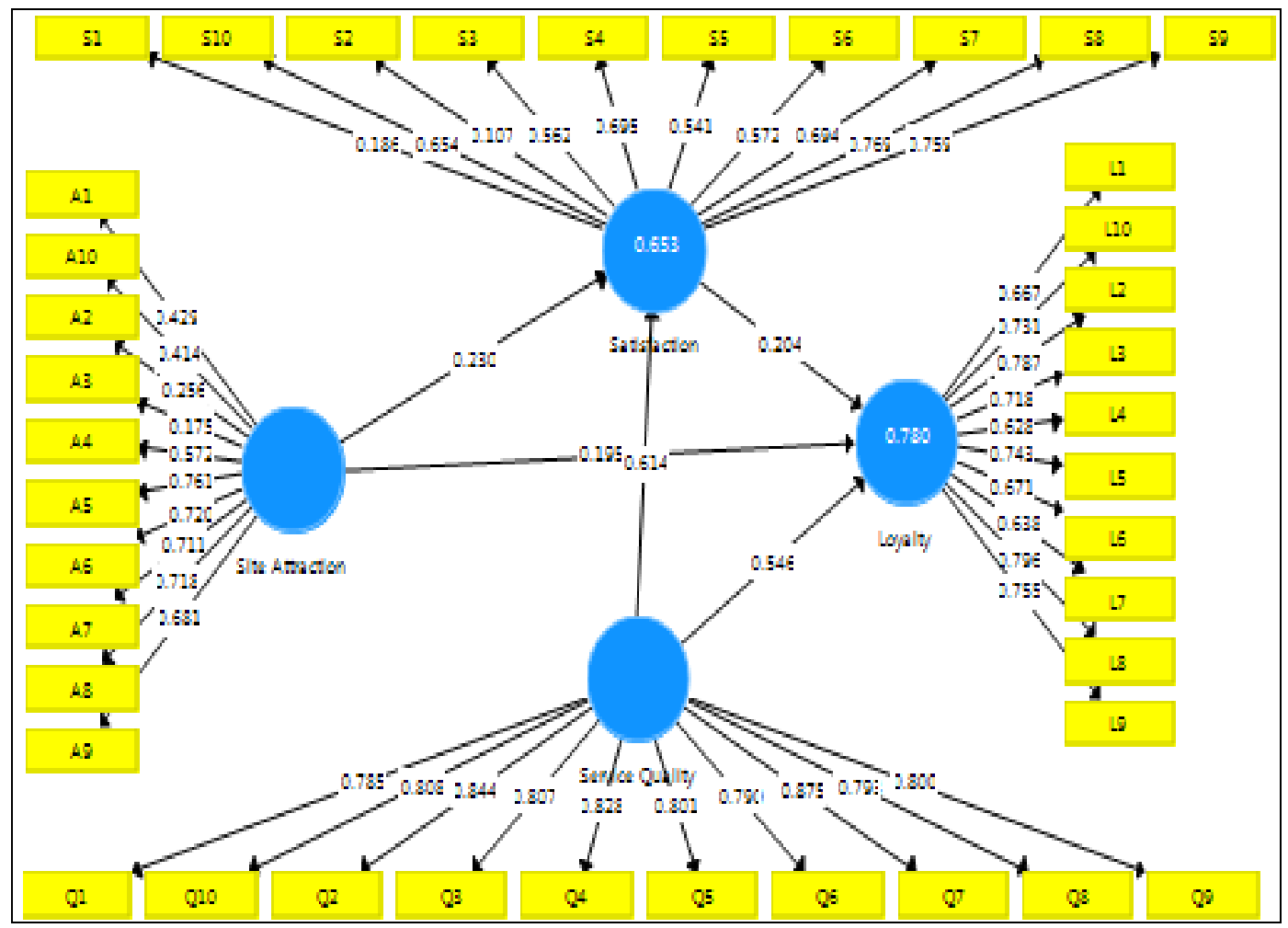

Figure 6. Output Estimate I

Based on Figure 6 and Table 2, the indicator of A1, A10, A2, A3, A4, A9, L1, L4, L6, $\mathrm{L} 7, \mathrm{~S} 1, \mathrm{~S} 10, \mathrm{~S} 2, \mathrm{~S} 3, \mathrm{~S} 4, \mathrm{~S} 5, \mathrm{~S} 6$, and $\mathrm{S}_{7}$ has a loading factor value of $<0.70$ in each, 
The Impact of Site Attraction and Service Quality on Loyalty Through Satisfaction:

A Case Study in Gunung Sewu Unesco Global Geopark, Indonesia

therefore the model is re-estimated by eliminating indicators that have a value of $<0.70$. The output estimation II is depicted in Figure 7 and the outer loadings II is described in Table 3 of path analysis using SmartPLS 3.0.

Table 2. Outer Loadings I

\begin{tabular}{|c|c|c|c|c|}
\hline Indicator & Loyalty & Satisfaction & Service Quality & Site Attraction \\
\hline $\mathrm{A} 1$ & & & & 0.429 \\
\hline A10 & & & & 0.414 \\
\hline $\mathrm{A} 2$ & & & & 0.256 \\
\hline A3 & & & & 0.175 \\
\hline A4 & & & & 0.572 \\
\hline A5 & & & & 0.761 \\
\hline $\mathrm{A6}$ & & & & 0.720 \\
\hline A7 & & & & 0.711 \\
\hline $\mathrm{A} 8$ & & & & 0.718 \\
\hline A9 & & & & 0.681 \\
\hline L1 & 0.667 & & & \\
\hline L1O & 0.731 & & & \\
\hline L2 & 0.787 & & & \\
\hline L3 & 0.718 & & & \\
\hline L4 & 0.628 & & & \\
\hline L5 & 0.743 & & & \\
\hline L6 & 0.671 & & & \\
\hline L7 & 0.638 & & & \\
\hline L8 & 0.796 & & & \\
\hline L9 & 0.755 & & & \\
\hline Q1 & & & 0.785 & \\
\hline Q10 & & & 0.808 & \\
\hline Q2 & & & 0.844 & \\
\hline Q3 & & & 0.807 & \\
\hline Q4 & & & 0.828 & \\
\hline Q5 & & & 0.801 & \\
\hline Q6 & & & 0.790 & \\
\hline Q7 & & & 0.875 & \\
\hline Q8 & & & 0.793 & \\
\hline Q9 & & & 0.800 & \\
\hline S1 & & 0.186 & & \\
\hline S10 & & 0.654 & & \\
\hline S2 & & 0.107 & & \\
\hline $\mathrm{S}_{3}$ & & 0.562 & & \\
\hline $\mathrm{S} 4$ & & 0.695 & & \\
\hline $\mathrm{S}_{5}$ & & 0.541 & & \\
\hline S6 & & 0.572 & & \\
\hline S7 & & 0.694 & & \\
\hline S8 & & 0.769 & & \\
\hline S9 & & 0.759 & & \\
\hline
\end{tabular}

Based on Figure 7 and Table 3, the indicator A8 and L3 has a loading factor value of $<0.70$ in each, therefore the model is re-estimated by eliminating indicators A8 and L3. The output estimation finalis depicted in Figure 8 and the outer loadings final is described in Table 4 of path analysis using SmartPLS 3.o. 


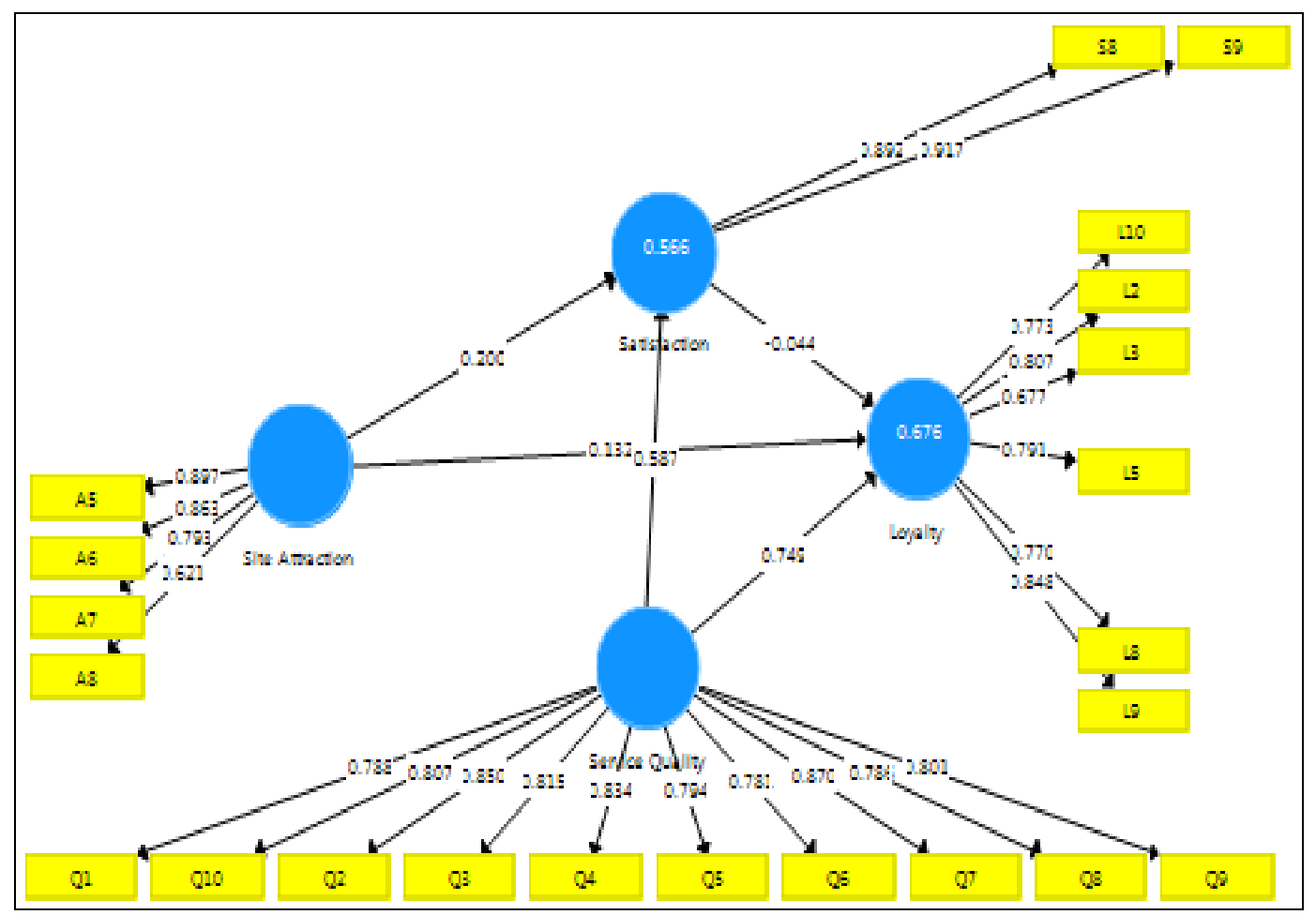

Figure 7. Output Estimate II

Table 3. Outer Loadings II

\begin{tabular}{|c|c|c|c|c|}
\hline Indicator & Loyalty & Satisfaction & Service Quality & Site Attraction \\
\hline A5 & & & & 0.897 \\
\hline A6 & & & & 0.861 \\
\hline A7 & & & & 0.793 \\
\hline A8 & & & & 0.621 \\
\hline L10 & 0.773 & & & \\
\hline L2 & 0.807 & & & \\
\hline L3 & 0.677 & & & \\
\hline L5 & 0.791 & & & \\
\hline L8 & 0.770 & & & \\
\hline L9 & 0.848 & & 0.788 & \\
\hline Q1 & & & 0.807 & \\
\hline Q10 & & & 0.850 & \\
\hline Q2 & & & 0.815 & \\
\hline Q3 & & & 0.814 & \\
\hline Q4 & & & 0.794 & \\
\hline Q5 & & & 0.781 & \\
\hline Q6 & & & 0.870 & \\
\hline Q7 & & & 0.786 & \\
\hline Q8 & & & 0.801 & \\
\hline Q9 & & & & \\
\hline S8 & & 0.892 & & \\
\hline S9 & & 0.917 & & \\
\hline
\end{tabular}


The Impact of Site Attraction and Service Quality on Loyalty Through Satisfaction:

A Case Study in Gunung Sewu Unesco Global Geopark, Indonesia

Based on Figure 8 and Table 4, the indicator has a loading factor value of $>0.70$ in each, then it is stated that all variables in the estimated model meet the criteria.

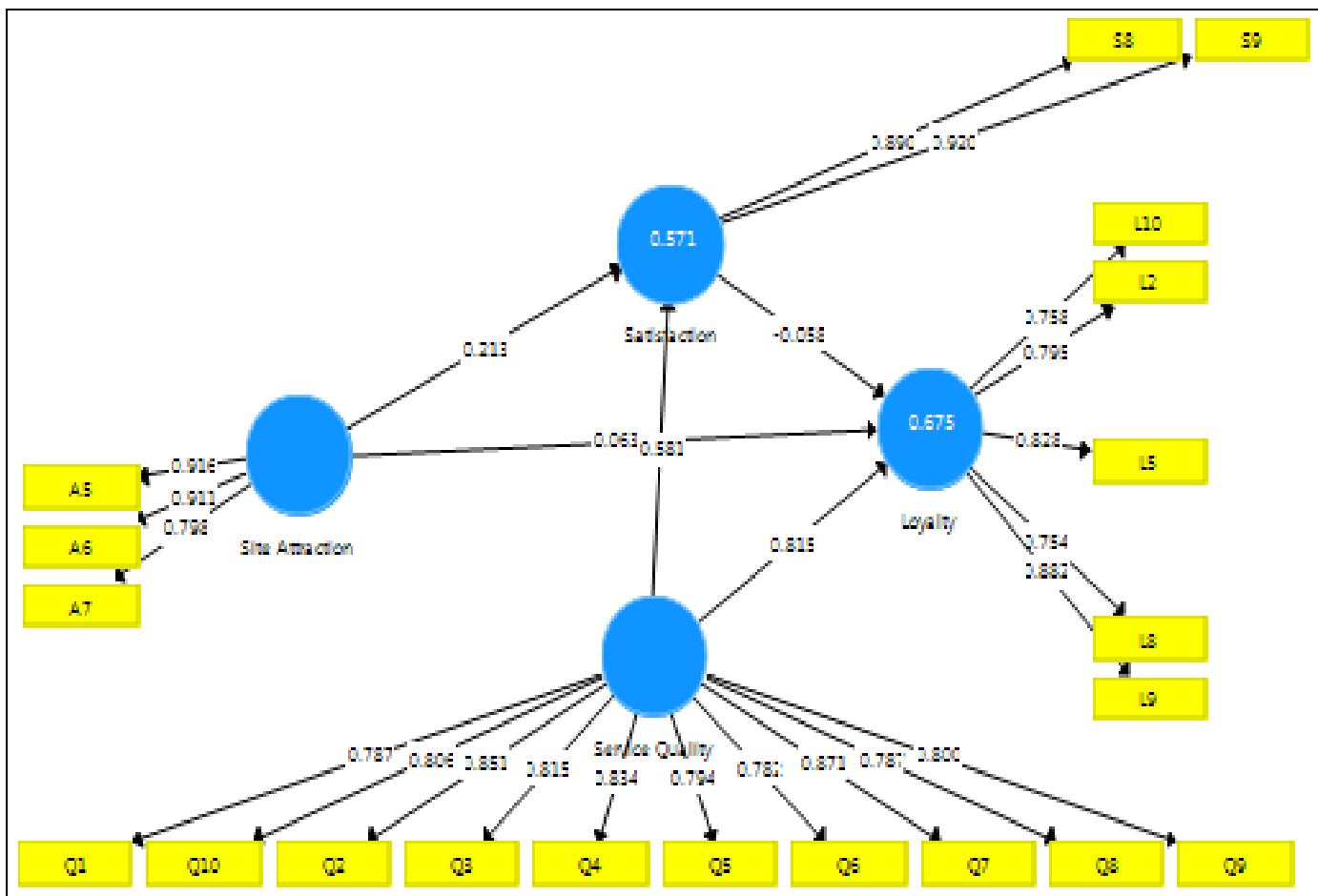

Figure 8. Output Estimate Final

Table 4. Outer Loadings Final

\begin{tabular}{|c|c|c|c|c|}
\hline Indicator & Loyalty & Satisfaction & Service Quality & Site Attraction \\
\hline A5 & & & & 0.916 \\
\hline A6 & & & & 0.911 \\
\hline A7 & & & & 0.798 \\
\hline L10 & 0.758 & & & \\
\hline L2 & 0.795 & & & \\
\hline L5 & 0.828 & & & \\
\hline L8 & 0.754 & & & \\
\hline L9 & 0.882 & & & \\
\hline Q1 & & & 0.787 & \\
\hline Q10 & & & 0.806 & \\
\hline Q2 & & & 0.851 & \\
\hline Q3 & & & 0.815 & \\
\hline Q4 & & & 0.834 & \\
\hline Q5 & & & 0.794 & \\
\hline Q6 & & & 0.782 & \\
\hline Q7 & & & 0.871 & \\
\hline Q8 & & & 0.787 & \\
\hline Q9 & & & 0.800 & \\
\hline S8 & & 0.890 & & \\
\hline S9 & & 0.920 & & \\
\hline & & & & \\
\hline
\end{tabular}


b. Discriminant validity

Discriminant validity is the value of the cross-loading factor to determine whether the variable has adequate discriminant, that is, if the value of the loading factor in the destination variable is greater than the value of the other loading factor variables.

Table 5. Cross loadings

\begin{tabular}{|c|c|c|c|c|}
\hline Indicator & Loyalty & Satisfaction & Service Quality & Site Attraction \\
\hline A5 & 0.683 & 0.587 & 0.699 & $\mathbf{0 . 9 6 1}$ \\
\hline A6 & 0.560 & 0.543 & 0.692 & $\mathbf{0 . 9 1 1}$ \\
\hline A7 & 0.427 & 0.595 & 0.601 & $\mathbf{0 . 7 9 8}$ \\
\hline L10 & $\mathbf{0 . 7 5 8}$ & 0.331 & 0.600 & 0.316 \\
\hline L2 & $\mathbf{0 . 7 9 5}$ & 0.481 & 0.538 & 0.396 \\
\hline L5 & $\mathbf{0 . 8 2 8}$ & 0.561 & 0.739 & 0.622 \\
\hline L8 & $\mathbf{0 . 7 5 4}$ & 0.373 & 0.665 & 0.428 \\
\hline L9 & $\mathbf{0 . 8 8 2}$ & 0.592 & 0.719 & 0.755 \\
\hline Q1 & 0.673 & 0.567 & $\mathbf{0 . 7 8 7}$ & 0.580 \\
\hline Q10 & 0.670 & 0.533 & $\mathbf{0 . 8 0 6}$ & 0.614 \\
\hline Q2 & 0.720 & 0.760 & $\mathbf{0 . 8 5 1}$ & 0.651 \\
\hline Q3 & 0.698 & 0.774 & $\mathbf{0 . 8 1 5}$ & 0.602 \\
\hline Q4 & 0.715 & 0.648 & $\mathbf{0 . 8 3 4}$ & 0.723 \\
\hline Q5 & 0.627 & 0.468 & $\mathbf{0 . 7 9 4}$ & 0.590 \\
\hline Q6 & 0.631 & 0.520 & $\mathbf{0 . 7 8 2}$ & 0.603 \\
\hline Q7 & 0.692 & 0.619 & $\mathbf{0 . 8 7 1}$ & 0.653 \\
\hline Q8 & 0.611 & 0.514 & $\mathbf{0 . 7 8 7}$ & 0.569 \\
\hline Q9 & 0.606 & 0.547 & $\mathbf{0 . 8 0 0}$ & 0.574 \\
\hline S8 & 0.502 & $\mathbf{0 . 8 9 0}$ & 0.610 & 0.539 \\
\hline S9 & 0.560 & $\mathbf{0 . 9 2 0}$ & 0.727 & 0.639 \\
\hline
\end{tabular}

From Table 5 it can be seen that the site attraction variable correlation with the indicator is greater than the indicator correlation with other variables; as well as loyalty, service quality, and satisfaction variables. This shows that latent variables predict indicators on their blocks are better than indicators in other blocks, so it is stated that all variables in the estimated model meet the criteria. Test to assess variable validity is done by looking at the value of Average Variance Extracted (AVE). Variables are valid if the AVE value of each variable is greater than 0.50. Output results show that AVE value for loyalty variable is $0.647>0.50$, satisfaction variable is $0.818>0.50$, service quality variable is $0.661>0.50$, and site attraction variable is $0.768>0.50$. From Table 6 , the AVE of each variable is greater than 0.50 , then variables are declared valid.

c. Undimensionality Test

To ensure that there are no problems related to measurement, the testing of the model's undimensionality is done by testing the outer model. The undimensionality test is a variable reliability test that is measured using two criteria, namely, Composite Reliability and Cronbachs Alpha from indicator blocks that measure variables.

Variables are declared reliable if the Composite Reliability value and the Cronbachs Alpha value of each variable is greater than 0.70. Output results show that Composite Reliability value for loyalty variable is $0.901>0.70$, satisfaction variable is $0.900>0.70$, service quality variable is $0.951>0.70$, and site attraction variable is $0.908>0.70$. Output results show that Cronbachs Alpha value for loyalty variable is $0.864>0.70$, satisfaction variable is $0.779>0.70$, service quality variable is $0.943>$ 0.70 , and site attraction variable is $0.848>0.70$. 
The Impact of Site Attraction and Service Quality on Loyalty Through Satisfaction:

A Case Study in Gunung Sewu Unesco Global Geopark, Indonesia

Table 6. Average Variance Extracted

\begin{tabular}{|c|c|c|c|c|}
\hline AVE/Variables & Loyalty & Satisfaction & Service Quality & Site Attraction \\
\hline AVE & 0.647 & 0.818 & 0.661 & 0.768 \\
\hline
\end{tabular}

From Table 7, the output results show that the Composite Reliability value and the Cronbachs Alpha value of each variable is greater than 0.70 , then variables are declared reliable.

Table 7. Undimensionality Test

\begin{tabular}{|l|c|c|c|c|}
\hline \multicolumn{1}{|c|}{ Test/Variables } & Loyalty & Satisfaction & Service Quality & Site Attraction \\
\hline Composite Reliability & 0.901 & 0.900 & 0.951 & 0.908 \\
\hline Cronbachs Alpha & 0.864 & 0.779 & 0.943 & 0.848 \\
\hline
\end{tabular}

\section{Structural (Inner) Model Test}

The first test of the structural model is done by considering the R-square value which is a goodness-fit model test. Based on the model, the effect of site attraction and service quality on satisfaction shows an R-square value of 0.571 . It is interpreted that satisfaction variable can be explained by site attraction variable and service quality variable of $57.1 \%$ while the remaining $100 \%-57.1 \%=42.9 \%$ is explained by other variables outside the model. The effect of site attraction, service quality, and satisfaction on loyalty shows an R-square value of 0.675. From Table 8, it is interpreted that loyalty variable can be explained by site attraction variable, service quality variable, and satisfaction variable of $67.5 \%$ while the remaining $100 \%-67.5 \%=32.5 \%$ is explained by other variables outside the model.

Table 8. R-square

\begin{tabular}{|c|c|c|}
\hline R-square/Variables & Satisfaction & Loyalty \\
\hline R-square & 0.571 & 0.675 \\
\hline
\end{tabular}

The second test is done by considering the significance of the influence between the variables on the parameter coefficient value, and it is significant, if the significance value of $t$ statistic is greater than the significance value of $t$ table $5 \%$ of 1.96 . Based on Table 9, it can be concluded that satisfaction directly affects loyalty with a coefficient of - 0.058 but not significant with a statistical t value of $0.426<1.96$ (answer hypothesis $\mathrm{H}_{5}$ ).

Table 9. Path Coefficients

\begin{tabular}{|l|c|c|}
\hline \multicolumn{1}{|c|}{ Variables } & Coefficient & t Statistic \\
\hline Satisfaction -> Loyalty & -0.058 & 0.426 \\
\hline Service Quality -> Loyalty & 0.815 & 5.741 \\
\hline Service Quality -> Satisfaction & 0.581 & 4.039 \\
\hline Site Attraction -> Loyalty & 0.063 & 0.456 \\
\hline Site Attraction -> Satisfaction & 0.213 & 1.197 \\
\hline
\end{tabular}

Service quality has a direct effect on loyalty with a coefficient of 0.815 and significant with a statistical $t$ value of $5.741>1.96$ (answer the H2 hypothesis), and service quality also has a direct effect on satisfaction with a coefficient of 0.581 and significant with a statistical $t$ value of $4.039>1.96$ (answer the $\mathrm{H}_{4}$ hypothesis). Site attraction has a direct effect on loyalty with a coefficient of 0.063 but not significant with a statistical t value of $0.456<1.96$ (answer the $\mathrm{H} 1$ hypothesis), and site attraction also has 
a direct effect on satisfaction with a coefficient of 0.213 but not significant with a statistical t value of $1.197<1.96$ (answer the H3 hypothesis).

\section{CONCLUSIONS AND FUTURE WORK}

After it was designated as a National Geopark in 2010, the number of tourist visit of Gunung Sewu Geopark with its 13 sites in Gunungkidul district has increased. The number of tourist visits then has increased more when Geopark was crowned as Global Geopark by UNESCO in 2015. However, the data shows that the number of tourist visits in the Nglanggeran tourist destination has experienced a decrease. This study has presented to provide information for management to increase the number of tourist visits of Nglanggeran. The analysis technique in this study is path analysis used on SmartPLS 3.0. We have examined the impact of site attraction and service quality on loyalty through satisfaction as an intervening variable. The results showed that site attraction has direct effect on satisfaction and loyalty but not significant, meanwhile service quality has direct effect and a significant effect on satisfaction and loyalty, and satisfaction has direct effect on loyalty but not significant. Increasing site attraction will provide opportunities for management to affect satisfaction and loyalty which can ultimately increase the number of tourist visits. The value of R-square $67.5 \%$, which means $32.5 \%$ is explained by other causes beyond the research model.

For further research, it is recommended to add other independent variables to support more the research model. The limitation of this study is that the data was not taken during the holiday season. Hence, the variation of respondents was limited.

\section{Acknowledgement}

This research is supported by Technology University of Yogyakarta.

\section{REFERENCES}

Belber, B.G., \& Erdoğan, Y. (2019). Assessments as regard of service quality of touristic consumers who participate in equestrian trekking activities: An application in core Cappadocia, Turkey. GeoJournal of Tourism and Geosites, 24(1), 74-87.

Burton, R. (1995). Travel Geography. London: Pitman Publishing.

Chaffey, D. (2009). E-business and e-commerce management: Strategy, implementation, and practice, $\left(4^{\text {th }}\right.$ ed). Prentice Hall.

Fang, Y.H. (2019). An app a day keeps a customer connected: Explicating loyalty to brands and branded applications through the lens of affordance and service-dominant logic. Information \& Management, 56(3), 377-391.

Farsani, N.T., Coelho, C., \& Costa, C. (2010). Geotourism and geoparks as novel strategies for socio-economic development in rural areas. International Journal of Tourism Research, 13(1), 68-81.

Ghozali, I., \& Latan, H. (2015). Partial least squares: Konsep, teknik dan aplikasi menggunakan program SmartPLS 3.o ( Pertial least squares: Concepts, techniques and applications using SmartPLS 3.0 programs). Semarang: Diponegoro University.

Gremler, D.D., \& Brown, S.W. (1996). Service loyalty: its nature, impotance, and implications. Advancing Service Quality: A Global Perspective , 171-180.

Griffin, W.R., \& Moorhead, G. (2010). Organizational behavior managing people and organizations. USA: South-Western.

Guchait, P., Han, R., Wang, X., Abbott, J., \& Liu, Y. (2019). Examining stealing thunder as a new service recovery strategy: impact on customer loyalty. International Journal of Contemporary Hospitality Management, 31(2), 931-952.

Haarhoff, R., \& De Klerk, B. (2019). Destination south Africa: Analysis of destination awareness and image by international visitors. GeoJournal of Tourism and Geosites, 24(1), 201-211.

Iglesias, O., Markovic, S., \& Rialp, J. (2019). How does sensory brand experience influence brand equity? Considering the roles of customer satisfaction, customer affective commitment, and employee empathy. Journal of Business Research, 96, 343-354. 
The Impact of Site Attraction and Service Quality on Loyalty Through Satisfaction: A Case Study in Gunung Sewu Unesco Global Geopark, Indonesia

Kesari, B., \& Atulkar, S. (2016). Satisfaction of mall shoppers: A study on perceived utilitarian and hedonic shopping values. Journal of Retailing and Consumer Services, 31, 22-31.

Martinaityte, I., Sacramento, C., \& Aryee, S. (2019). Delighting the customer: Creativity-oriented highperformance work systems, frontline employee creative performance, and customer satisfaction. Journal of Management, 45(2), 728-751.

Martono, B. (2016). Berbagi pengalaman membangun \& mengembangkan geopark di Indonesia (Share experiences in building \& developing geoparks in Indonesia). Maritime Sector Coordinating Ministry.

Meesala, A., \& Paul, J. (2016). Service quality, consumer satisfaction and loyalty in hospital: Thinking for the future. Journal of Retailing and Consumer Services, 40, 261-269.

Mowen, J.C., \& Minor, M. (1998). Consumer behavior, (5 ${ }^{\text {th }}$ ed). New Jersey: Prentice Hall.

MualMaul. (2009). Sejarah geologi zona pegunungan selatanJawa Timur (Geological history of the mountain zone south of East Java). Wingman Arrows.

Nikolova, V., \& Sinnyovsky, D. (2019). Geoparks in the legal framework of the EU countries. Tourism management perspectives, 29, 141-147.

Pawonsari. (2013). Java Gunung Sewu Geopark. Central Java Government.

Roderick, B., \& Gregory, B.J. (2008). Investigating the service: A customer value perspective. Journal of Business Research, 62(7), 345-355.

Saboohi, H., Amini, A., \& Herawan, T. (2014). Increasing failure recovery probability of tourism-related web services. In Recent Advances on Soft Computing and Data Mining (pp. 517-527). Springer, Cham.

Samsudin, A. (2014). Nglanggeran tourism. Photo collections. Tourist Services of Gunungkidul District.

Scheidt, S., \& Chung, Q. B. (2019). Making a case for speech analytics to improve customer service quality: Vision, implementation, and evaluation. International Journal of Information Management, 45, 223-232.

Tasci, D. A., \& Kozak, M. (2006). Destination brands vs destination images: Do we know what we mean? Journal of Vacation Marketing, 12 (4), 299-185.

Taylor, A.S., \& Baker, L.T. (1994). An assessment of the relationship between service quality and customer satisfaction in the formation of consumers' purchase intentions. Journal of Retailing, $70(2), 163^{-178 .}$

Usmara, A. (2008). Strategi baru manajemen pemasaran (New marketing of management strategy). Jakarta: Amara Books.

Wilkie, W.L. (1994). Consumer behavior, ( $3^{\text {rd }}$ ed). New York: Jhon Wiley \& Sons Inc.

Wilson, A., Zeithamal, V.A., Bitner, M.J., \& Gremler, D.D. (2008). Services marketing. McGraw-Hill Education. Wright, S. (1934). The method of path coefficients. The Annals of Mathematical Statistics, 5(3), 161-215.

Zouros, N., \& Martini, G. (2003). Introduction to the European geoparks network. In NHM of Lesvos Petrified Forest. Proceedings of the 2nd international symposium of natural monuments and geological heritage. Greece: Lesvos: Natural History Museum of the Lesvos Petrified Forest: Lesvos, 17-21.

*** Tourist Services of Gunungkidul District. (2015). Gunungkidul District Tourism Potential. Yogyakarta.

*** Tourist Services of Gunungkidul District. (2016). Gunungkidul District Tourism Potential. Yogyakarta.

*** Tourist Services of Gunungkidul District. (2017). Gunungkidul District Tourism Potential. Yogyakarta.

*** Tourist Services of Gunungkidul District. (2018). Gunungkidul District Tourism Potential. Yogyakarta.

*** Tourist Services of Gunungkidul District. (2019). Files of Tourist Services of Gunungkidul District. Yogyakarta.

Submitted:

06.03.2019
Revised:

30.05.2019
Accepted and published online 24.06.2019 